\title{
Gender Diversity, Bonus Schemes, and Manager's Earnings Management Intention: An Experimental Study
}

\author{
I Putu Hendra Martadinata ${ }^{1, *}$ I Nyoman Putra Yasa ${ }^{1}$ Edy Sujana $^{1}$ \\ ${ }^{1}$ Department of Economic and Accounting, Universitas Pendidikan Ganesha, Singaraja, Indonesia \\ "Corresponding author. Email: hendra.martadinata@undiksha.ac.id
}

\begin{abstract}
This study aims to examine managers' intentions for earnings management based on gender differences and bonus schemes through experimental methods. The experiment was conducted on 57 Master of Accounting students at Gadjah Mada University, Yogyakarta. Hypothesis testing is done by analysis of variance (ANOVA). The results of this study indicate that the fixed bonus scheme can suppress the opportunistic behavior of managers to perform earnings management in both genders, indicated by the relatively low earnings management intention. Meanwhile, the variable bonus scheme increases the earnings management intention of male managers. This confirms that performance-based financial incentives can influence the opportunistic behavior of managers, especially male managers. The results of this study are expected to add to the literature review related to earnings management behavior in terms of difference in financial incentive schemes as a reward for performance achievements by considering the personal traits of managers. Practically, the results of this study are expected to be used as a consideration in an effort to reduce the opportunistic nature of managers, which have the potential to harm the company in the long term as a result of manipulation of financial statements.
\end{abstract}

Keywords: Bonus scheme, Earnings management, Gender.

\section{INTRODUCTION}

Earnings management practice is one of the topics that gets a lot of attention, especially in behavioural accounting research. Earnings management can be defined as the activity of manipulating company financial information with the aim of deceiving stakeholders [10]. Earnings management can take two forms. First, by overestimating costs when the company has exceeded the profit target [4]. Second, by underestimating costs so that profit increases [4]. Whatever the type or form, the practice of earnings management can be a violation of ethics because the reporting of financial information does not show the actual condition of the company. Earnings management is one of an example ethical dilemma case, and has become one of the most widely discussed ethical issues in the accounting world [15].

One of the factors that causes earnings management to occur is the existence of financial incentives that have the potential to be achieved by management. Profitability is one of the most common performance indicators to assess the performance of managers. When associated with financial incentives, the better the manager's performance, the higher the incentives obtained, so that management's focus is focused on achieving high profits. This often leads to opportunistic behaviour of managers, namely to practice earnings management.

Several studies have found that the scheme of providing incentives or bonuses to managers can affect managers' intentions to carry out earnings management. Greenfield, Norman, and Wier [7] found that the amount of bonuses determined by the performance of managers increases the potential for earnings management, as a result of the incentive to achieve the highest performance in order to obtain financial incentives. In addition, Beaudoin, Cianci, and Tsakumis [4] conducted a study comparing manager behavior among different bonus schemes. Beaudoin, Cianci, and Tsakumis [4] divide bonus schemes into two types, namely variable bonus schemes (bonuses are determined based on performance achievements) and fixed bonus schemes (bonuses are given in a constant 
amount regardless of the manager's performance). The results of the research by Beaudoin, Cianci, and Tsakumis [4] found that there was a greater discretionary expense reporting when bonuses were determined based on performance achievement (profit) compared to bonuses that were determined on a regular basis. This indicates an attempt by the manager to secure profits in the next period, so that the bonus to be received in the next period will be higher.

Furthermore, Martadinata [14] conducted research related to earnings management behavior based on the personal characteristics of managers and bonus schemes (variable bonuses and fixed bonuses). Consistent with the research results of Beaudoin, Cianci, and Tsakumis [4], Martadinata [14] found that the variable bonus scheme strengthens earnings management intentions, especially for individuals who have a high love of money nature. Overall, the scheme of providing financial incentives for managers' performance can be a factor that influences managers' intentions to carry out earnings management.

Although various literatures state that financial incentives are a factor causing earnings management, various studies have found that the characteristics inherent in individuals can be an internal factor causing managers' deviant behavior. Earnings management is an example of managers' opportunistic behavior [14], and this can be attributed to the manager's personal trait, one of which is gender. Gender is an interesting predictor to discuss, especially in topics involving ethical dilemmas. Specifically, this study uses gender as another predictor of earnings management because this variable can be associated with individual opportunistic behavior based on their risk preferences [5], [6], [12]. Earnings management is a risky action that can cause long-term problems for the company, but offers managers the opportunity to maximize their personal profits.

The relationship of gender to ethical decisions can be linked to the risk preferences of each gender. Kastlunger et al. [12] in their research examining taxpayer compliance found that men tend to be more daring in taking risks to maximize their personal benefits, in this case by avoiding taxes. Furthermore, Brockmann et al. [5] found differences in risk preferences in decision making between men and women in various behavioral experimental studies. This was confirmed by D'Attoma et al. [6] which states that women are more likely to avoid risk than men and this is a natural trait of humans themselves.

Regarding earnings management practices, several studies have found differences in earnings management behavior based on gender differences. In this case, female managers tend to show lower earnings management behavior than male managers [9], [3], [17], [18]. This is thought to be related to the nature of men who tend to be more opportunistic, so they try to maximize their personal benefits [5], [12], [6]. However, earnings management behavior, especially that shown by male managers can allegedly be suppressed, if there are ways to limit the opportunistic behavior that appears, one of which is by providing a bonus scheme that is not tied to the manager's performance achievement [4], [7], [14].

Overall, previous studies indicate that financial incentives can be a factor that causes managers' tendencies to carry out earnings management, and this tendency can also be associated with opportunistic behavior inherent in certain genders. But, to the best of the researcher's knowledge, current behavioral accounting research has not tested managers' behavior based on gender in any particular bonus scheme. Financial incentives can lead to opportunistic behavior of managers, but the intensity of this opportunistic behavior is thought to be different between the two types of gender. Therefore, this study aims to examine managers' intentions for earnings management based on gender differences and bonus schemes through experimental methods. More specifically, this study aims to determine whether differences in bonus schemes in evaluating manager performance can lead to differences in earnings management intentions of managers of different genders. This research is expected to add to the literature review related to earnings management behavior in the scheme of providing financial incentives from a gender perspective.

\section{LITERATURE REVIEW \& HYPOTHESIS DEVELOPMENT}

\subsection{Earnings Management}

Earnings management is a form of manipulation of financial statements that can damage the harmony of the relationship between the company and its stakeholders [14]. Manipulative activities in earnings management are identical with the manager's goal to obtain financial incentives for his personal interests. Financial incentives, in this case called "bonuses", aim to motivate managers to achieve performance targets desired by stakeholders [14]. However, the provision of financial incentives is often exploited by the opportunistic nature of managers, which encourages managers to manipulate financial statements [1], [14].

Earnings management practices can be divided into two types, namely accrual-based earnings management and real earnings management [16]. Accrual-based earnings management is a form of financial statement manipulation by violating accounting provisions contained in Generally Accepted Accounting Principles (GAAP) [2], [16]. While real earnings management is a form of earnings management by arranging and changing the timing of real transactions, but this is not a violation of GAAP and does not cause misstatements in 
financial statements [2], [11], [14]. The focus in this study is real earnings management, because real earnings management is a form of earnings management that does not violate accounting principles, but creates an ethical dilemma that can encourage managers' opportunistic behaviour for personal gain.

\subsection{Gender and Earnings Management Behaviour}

Gender is one of the variables that is widely studied in behavioural research, especially in ethical decision making. The perspective on personal gain is often a factor that influences the decisions taken. Earnings management is one of the managerial decisions, which is often associated with ethical issues, especially regarding financial manipulation activities.

Several studies have examined the effect of gender on earnings management, and found a tendency for female managers to suppress earnings management practices. Hala [9] found that women in supervisory and top management positions contribute to efforts to improve financial statements by reducing the possibility of earnings management practices. In line with Hala [9], Umer et al. [17] found that female CEOs exhibited effective and transparent managerial decision-making, and tended to reduce management practices. While in the context of Indonesia, Azizah et al. [3] found that female financial directors can suppress real earnings management practices in LQ 45 companies in Indonesia.

Zalata et al. [18] stated that female directors have a strong motivation to limit managerial opportunism, so that it causes low earnings management behavior shown in companies with female directors. This can be related to the statement of Brockmann et al. [5] and D'Attoma et al. [6], that women are more risk averse than men. Earnings management is an action that has the risk of causing long-term problems for the company, so that female managers are better able to suppress managerial opportunism compared to male managers. Therefore, if there is a financial incentive that is influenced by performance achievement, this study suspects that earnings management intentions are shown by male managers compared to female managers.

\subsection{Bonus Schemes, Gender and Managers' Opportunistic Behaviour}

Financial incentives are an effort to motivate managers to achieve the performance expected by stakeholders. According to Beaudoin, Cianci, and Tsakumis [4], the provision of financial incentives can be done through two types of schemes, namely permanently based on a percentage of employee salaries, or variable based on employee performance achievements. In the fixed bonus scheme, performance achievements will not affect the bonuses received by employees.

This study presumes that earnings management intentions will be different with respect to different bonus schemes. This is based on several previous research findings that show the effect of bonus schemes on the opportunistic behavior of managers to perform earnings management. Almadi and Lazic [1] found that variable bonuses (bonuses given based on performance achievements) lead to opportunistic behavior of managers by manipulating earnings in financial statements.

Consistent with Almadi and Lazic [1], Martadinata [14] found that bonuses given variablely strengthen managers' intentions to carry out earnings management. Giving bonuses in a variable way can motivate the achievement of manager performance, but it has the potential to cause opportunistic behavior for managers to manage earnings [14]. Different behavior is shown by managers with fixed bonus schemes (based on a percentage of the manager's salary), namely managers show lower earnings management intentions [14]. This can be related to the fixed bonus scheme itself, that the bonus amount is given regularly without being influenced by performance achievements, so that the absence of financial benefits for managers in making manipulative decisions can suppress managers' opportunistic behavior [14].

When it comes to gender, this study suggests that bonus schemes can suppress the opportunistic behavior that male managers tend to exhibit. In the variable bonus scheme, male managers show higher earnings management intentions than female managers. Whereas in the fixed bonus scheme, the absence of financial benefits for managers to carry out earnings management will suppress managers' opportunistic behavior, so that earnings management intentions for both genders will be relatively low. Based on this, the proposed hypotheses are:

$\mathrm{H}_{1}$ : Variable bonus scheme significantly strengthens earnings management intentions in male managers

$\mathrm{H}_{2}$ : Variable bonus scheme does not strengthen earnings management intentions in female managers

$\mathrm{H}_{3}$ : In the variable bonus scheme, male managers show significantly higher earnings management intentions than female managers

$\mathrm{H}_{4}$ : In the fixed bonus scheme, there is no significant difference in earnings management intentions between male and female managers 


\section{RESEARCH METHODS}

\subsection{Experimental Design}

This study uses a $2 \times 1$ between subject experimental design. The bonus scheme is the treatment variable, while gender (male and female) is the measured variable. The participants in this experiment were Master of Accounting students at Gadjah Mada University Yogyakarta who had taken managerial accounting courses. The reason behind choosing students as participants is because students can represent the role and mentality of managers in the company and have the ability to work on cases involving ethical dilemmas [13]

There are two experimental scenarios in this study, which were adopted from the research of Greenfield, Norman, and Wier [7] and Martadinata [14]. Experimental scenarios are distinguished based on bonus schemes, namely variable bonuses and fixed bonuses. In scenario A, the bonus is given in a variable manner so that earnings management will increase the bonus received by the manager (in table 1 ). Whereas in scenario $\mathrm{B}$, the bonus is given regularly so that earnings management does not affect the bonus received by the manager. The scenarios are given randomly, then participants will be divided into 4 (four) groups based on the bonus scheme and gender (in table 2).

Table 1. Experimental design

\begin{tabular}{|l|c|c|}
\hline \multirow{2}{*}{ Bonus Scheme } & \multicolumn{2}{|c|}{ Gender } \\
\cline { 2 - 3 } & Male & Female \\
\hline Variable Bonus & 1 & 2 \\
\hline Fixed Bonus & 3 & 4 \\
\hline
\end{tabular}

\subsection{Variable Measurement}

This study uses gender variables and bonus schemes as independent variables. Meanwhile, earnings management intention is the dependent variable. Gender in this case consists of men and women, while the bonus scheme is divided into two, namely variable bonus schemes and fixed bonus schemes. Meanwhile, earnings management intention is the extent to which individuals support or reject proposed decisions that are classified as real earnings management. Earnings management intentions were measured using a 7-point Likert scale.
The experimental instrument contains a short story about a fictitious company experiencing performance problems that have the potential to cause the company's failure to achieve the predetermined profit target. This instrument was adopted from the research of Greenfield, Norman, and Wier [7] and Martadinata [14]. Participants were asked to imagine themselves as top managers in the company. Participants are faced with an ethical dilemma to carry out real earnings management by postponing an activity, in the hope that the postponement of the activity can reduce operating costs so that profit achievement will increase. In the variable bonus scenario, the participant bonus is determined based on performance achievement, in this case profitability. Meanwhile, in the fixed bonus scenario, the participant's performance does not affect the amount of bonus earned. Participants were asked to indicate their intention to perform earnings management.

\subsection{Data Analysis Technique}

Hypothesis testing was carried out using the statistical analysis of variance (ANOVA) method to determine differences in earnings management intentions in each experimental group, with a significance level $(\alpha)=0.05$. Hypothesis testing was carried out with the help of the IBM Statistical Package for the Social Sciences (SPSS) 25 application.

\section{RESULTS \& DISCUSSION}

\subsection{Data Description}

The experiment was conducted on 57 Master of Accounting students at Gadjah Mada University, Yogyakarta. A total of 26 male students and 31 female students. Regarding work experience, as many as 11 students have worked, 11 students are working, and 35 students have not worked. The average age of the participants was 26 years. After the response data was collected, then the participants were grouped by gender and experimental treatment, so that the participants were divided into 4 (four) groups. The details of the division of the experimental group along with the average score of earnings management intentions are listed in Table 2.

Table 2. Experimental group

\begin{tabular}{|l|c|c|}
\hline \multirow{2}{*}{ Bonus Scheme } & Male & Gender \\
\cline { 2 - 3 } Variable Bonus & $\mathrm{n}=14$ & $\mathrm{n}=12$ \\
\hline Fixed Bonus & Average Intention Score $=5,07$ & Average Intention Score $=3,67$ \\
\hline & $\mathrm{n}=12$ & $\mathrm{n}=19$ \\
& Average Intention Score $=3,25$ & Average Intention Score $=3,37$ \\
\hline
\end{tabular}

4.2. Hypotheses Testing

Before testing the hypotheses, normality and homogeneity tests were carried out. The results of the 
homogeneity test using Levene's test showed that the data met the homogeneous criteria (table 3). As for the normality test, the result showed that the data were not normally distributed. This is caused by the skewness of the data distribution. The ANOVA test remains robust even though the research data does not meet the assumption of normality (table 4), provided that it is caused by the skewness of the data distribution and does not contain outliers [8].

After testing the assumptions of normality and homogeneity, the data were then analyzed using

Table 3. Levene's homogeneity test
ANOVA to test the proposed hypothesis. Based on the test results listed in Table 5, it was found that there was a weak interaction between the gender variable and the bonus scheme on earnings management intentions (Sig. 0.73). Based on the main effect test, it was found that the bonus scheme had a significant effect on earnings management intentions (Sig. 0.14), while gender did not significantly affect earnings management intentions (Sig. 0.128).

\begin{tabular}{|l|l|r|r|r|r|}
\hline & & Levene Statistic & \multicolumn{1}{c|}{ df1 } & \multicolumn{1}{c|}{ df2 } & \multicolumn{1}{c|}{ df3 } \\
\hline Intention & Based on Mean & 0,390 & 3 & 53 & 0,761 \\
\cline { 2 - 6 } & Based on Median & 0,343 & 3 & 53 & 0,794 \\
\cline { 2 - 6 } & Based on Median and with adjusted df & 0,343 & 3 & 41,538 & 0,794 \\
\cline { 2 - 6 } & Based on trimmed mean & 0,386 & 3 & 53 & 0,763 \\
\hline
\end{tabular}

Table 4. ANOVA test results

\begin{tabular}{|l|r|r|r|r|r|}
\hline \multicolumn{1}{|c|}{ Source } & Type III Sum of Squares & \multicolumn{1}{c|}{ df } & \multicolumn{1}{c|}{ Mean Square } & F & Sig. \\
\hline Corrected Model & $29.979 a$ & 3 & 9.993 & 4.195 & .010 \\
\hline Intercept & 811.148 & 1 & 811.148 & 340.478 & .000 \\
\hline Scheme & 15.454 & 1 & 15.454 & 6.487 & .014 \\
\hline Gender & 5.692 & 1 & 5.692 & 2.389 & .128 \\
\hline Scheme * Gender & 7.980 & 1 & 7.980 & 3.350 & .073 \\
\hline Error & 126.266 & 53 & 2.382 & & \\
\hline Total & 990.000 & 57 & & & \\
\hline Corrected Total & 156.246 & 56 & & & \\
\hline
\end{tabular}

a. R Squared $=.192($ Adjusted R Squared $=.146)$

Table 5. Post Hoc Tukey's HSD test results

\begin{tabular}{|c|c|c|c|c|}
\hline (I) Group & (J) Group & Mean Difference (I-J) & Std. Error & Sig. \\
\hline \multirow[t]{3}{*}{ Variable Bonus - Male } & Variable Bonus - Female & 1.40 & 607 & .108 \\
\hline & Fixed Bonus - Male & $1.82^{*}$ & 607 & .021 \\
\hline & Fixed Bonus - Female & $1.70^{*}$ & .544 & .015 \\
\hline \multirow[t]{3}{*}{ Variable Bonus - Female } & Variable Bonus - Male & -1.40 & .607 & .108 \\
\hline & Fixed Bonus - Male & .42 & .630 & .911 \\
\hline & Fixed Bonus - Female & .30 & .569 & .953 \\
\hline \multirow[t]{3}{*}{ Fixed Bonus - Male } & Variable Bonus - Male & $-1.82^{*}$ & 607 & .021 \\
\hline & Variable Bonus - Female & -.42 & .630 & .911 \\
\hline & Fixed Bonus - Female & -.12 & .569 & .997 \\
\hline \multirow[t]{3}{*}{ Fixed Bonus - Female } & Variable Bonus - Male & $-1.70^{*}$ & .544 & .015 \\
\hline & Variable Bonus - Female & -.30 & .569 & .953 \\
\hline & Fixed Bonus - Male & .12 & .569 & .997 \\
\hline
\end{tabular}

*. The mean difference is significant at the .05 level.

To determine the significance of differences in earnings management intentions, this study used post hoc testing with the Tukey's HSD method. The results of the post hoc test can be seen in Table 5. The post hoc test results in Table 5 can be interpreted as follows:

1) There is a significant difference between the Variable Bonus group - Male (intention score 5.07) and the Fixed Bonus group - Male (3.25) with a value of Sig. 0.21. This means that the variable bonus scheme significantly strengthens the earnings management intention of male managers, so $\mathrm{H} 1$ is accepted.
2) There is no significant difference between the Variable Bonus - Female group (intention score 3.67) and the Fixed Bonus group - Female (3.37) with a Sig value. 0.953. This means that the variable bonus scheme does not strengthen the earnings management intentions of female managers, so $\mathrm{H} 2$ is accepted.

3) There is no significant difference between the Variable Bonus group - Male (intention score 5.07) and the Variable Bonus group - Female (3.67) with a value of Sig. 0.108, so H3 is rejected. Although the direction of the data is in accordance with the proposed hypothesis, in this case the earnings 
management intention of male managers is higher than female managers, but the difference is not significant in the variable bonus scheme.

4) There is no significant difference between the Fixed Bonus group - Male (intention score 3.25) and the Fixed Bonus group - Female (3.37) with a value of Sig. 0.997. This means that in the fixed bonus scheme, there is no significant difference in earnings management intentions between male managers and female managers, so $\mathrm{H} 4$ is accepted.

\subsection{Discussions}

This study examines the effect of gender differences and bonus schemes on earnings management intentions. This research was conducted based on the assumption that the opportunistic behaviour shown by male managers can be suppressed by the treatment of a fixed bonus scheme that eliminates financial incentives based on the manager's performance. The results of this study showed various intentions in each experimental group.

Based on the results of hypothesis testing, it is found that the variable bonus scheme strengthens the earnings management intention of male managers, as evidenced by the lower earnings management intentions of the fixed bonus scheme compared to the variable bonus scheme of male managers. This indicates that the bonus is still able to reduce the opportunistic behaviour of managers, especially male managers, because the bonuses given are not influenced by performance achievements, so managers are not motivated to pursue profitability by doing earnings management. Meanwhile, for female managers, the increase in intention was not significant. This is consistent with the research of Zalata et al. [18] that female managers are able to limit the nature of managerial opportunism. In addition, this can be related to several previous studies conducted by Kastlunger et al. [12], Brockmann et al. [5], and D'Attoma et al. [6], that there are differences in risk preferences based on gender in taking advantage of opportunities for personal gain.

Regarding the difference in intentions seen in each treatment, this study found that in the fixed bonus scheme, there was no difference in earnings management intentions between male and female managers, with low intention scores (3.25 and 3.37, respectively). This is in accordance with the hypothesis that the fixed bonus scheme can reduce the manager's desire to carry out earnings management, because performance achievements will not affect the amount of bonuses that will be received. However, in the variable bonus scheme, the results of hypothesis testing show that there is no significant difference in intentions between male and female managers. This is not in accordance with the proposed hypothesis (H2). Although the direction of the data shows that the earnings management intention of male managers (intention score of 5.07) is higher than that of female managers (intention score of 3.67), the difference is not significant. This is thought to be caused by the type of earnings management used in the experiment, namely real earnings management. Real earnings management is one form of unethical action, but the action does not violate GAAP. Because it does not violate GAAP, managers tend to judge that real earnings management is not a form of serious ethical violation, so they have a relatively strong intention to carry out earnings management. However, it is hoped that this assumption can be tested in future research, by comparing managers' intentions between accrual-based earnings management and real earnings management.

Overall, the results of this study are expected to contribute to the development of behavioural accounting research in terms of earnings management. Bonus schemes are known to have a significant influence on managers' intentions to carry out earnings management, both for male and male managers, so a performance appraisal system is needed that can suppress managers' opportunistic behaviour. This study found that the fixed bonus scheme can suppress the opportunistic behaviour of managers, especially in male managers. It should be considered that the fixed bonus scheme has the potential to reduce the performance motivation of managers. However, when it comes to preventing manipulation of financial statements, this study finds the effectiveness of the fixed bonus scheme in reducing managers' intentions to perform earnings management.

\section{CONCLUSIONS}

The results of this study indicate that the fixed bonus scheme can suppress the opportunistic behaviour of managers to perform earnings management, while the variable bonus scheme increases the earnings management intention of male managers. This confirms that financial incentives can influence managers' opportunistic behaviour, especially male managers. The results of this study are expected to add to the study of behavioural accounting literature, especially related to earnings management behaviour by considering the personal traits of managers and performance reward schemes through financial incentives. Practically, the results of this study are expected to be used as a consideration in an effort to reduce the opportunistic nature of managers, which have the potential to harm the company in the long term as a result of manipulation of financial statements.

This study has several limitations. First, this study uses an experimental method that does not describe the real conditions in managerial decision making. Although this experiment has considered the selection of a sample that is able to represent the nature of managers, caution is needed in interpreting the results of 
this study. Second, this research only focuses on real earnings management. Future research is expected to be able to compare the behavior of managers based on gender between real earnings management and accrualbased earnings management scenarios, so that this can further clarify the concept of manager's opportunistic behavior between gender differences.

\section{REFERENCES}

[1] Almadi, Madi; Lazic, Philip. CEO incentive compensation and earnings management: The implications of institutions and governance systems. Management Decision, 2016.

[2] Asim, Aysha; Ismail, Aisha. Impact of leverage on earning management: Empirical evidence from the manufacturing sector of Pakistan. Journal of Finance and Accounting Research, 2019, 1.1: 7091.

[3] Azizah, Widyaningsih, et al. Earnings Management in Indonesia: Are Women Always Under. IOSR Journal of Business and Management (IOSRJBM), 2019, 21.11: 42-46.

[4] Beaudoin, Cathy A.; Cianci, Anna M.; Tsakumis, George T. The impact of CFOs' incentives and earnings management ethics on their financial reporting decisions: The mediating role of moral disengagement. Journal of business ethics, 2015, 128.3: 505-518.

[5] Brockmann, Hilke; Genschel, Philipp; Seelkopf, Laura. Happy taxation: increasing tax compliance through positive rewards? Journal of Public Policy, 2016, 36.3: 381-406.

[6] D’attoma, John; Volintiru, Clara; Steinmo, Sven. Willing to share? Tax compliance and gender in Europe and America. Research \& Politics, 2017, 4.2: 2053168017707151

[7] Greenfield, A. C.; Norman, Carolyn Strand; Wier, Benson. The effect of ethical orientation and professional commitment on earnings management behavior. Journal of Business Ethics, 2008, 83.3: 419-434.

[8] Gudono. Analisis Data Multivariat. Edisi 4. Yogyakarta: BPFE Yogyakarta, 2015.

[9] Hala, Ganis Sepsika, et al. Women on boards and earnings management: What really matters. Jurnal Keuangan dan Perbankan, 2019, 23.4: 566-578.

[10] Healy, Paul M.; Wahlen, James M. A review of the earnings management literature and its implications for standard setting. Accounting horizons, 1999, 13.4: 365-383.
[11] Herda, David N.; Dowdell Jr, Thomas D.; Bowlin, William F. Auditor response to earnings management through real transactions. The Journal of Theoretical Accounting Research, 2012, 7.2: 82.

[12] Kastlunger, Barbara, et al. Sex differences in tax compliance: Differentiating between demographic sex, gender-role orientation, and prenatal masculinization (2D: 4D). Journal of economic psychology, 2010, 31.4: 542-552.

[13] Liyanarachchi, Gregory; Newdick, Chris. The impact of moral reasoning and retaliation on whistle-blowing: New Zealand evidence. Journal of business ethics, 2009, 89.1: 37-57.

[14] Martadinata, I Putu Hendra. Pengaruh Idealisme dan Love of Money Terhadap Intensi Untuk Melakukan Manajemen Laba dalam Skema Pemberian Bonus. Thesis: Universitas Gadjah Mada, 2017

[15] Merchant, Kenneth A.; Rockness, Joanne. The ethics of managing earnings: An empirical investigation. Journal of Accounting and Public policy, 1994, 13.1: 79-94.

[16] Roychowdhury, Sugata. Earnings management through real activities manipulation. Journal of accounting and economics, 2006, 42.3: 335-370.

[17] Umer, Ramsha, Et Al. The Gender Diversity and Earnings Management Practices: Evidence from Pakistan. City University Research Journal, 2020, 10.2: 342-357.

[18] Zalata, Alaa Mansour; Tauringana, Venancio; Tingbani, Ishmael. Audit committee financial expertise, gender, and earnings management: Does gender of the financial expert matter? International review of financial analysis, 2018, 55: 170-183. 